\title{
TITLE PROBLEMS CONCERNING UNREGISTERED AND UNREGISTRABLE INTERESTS IN OIL AND GAS PROPERTIES
}

\author{
PETER G. SCHMIDT* and WILLIAM H. BONNEY**
}

\begin{abstract}
Sir Robert Torrens in developing the Torrens System of Land Titles sought to devise a title registration system which would be reliable, simple, cheap, speedy and suited to the needs of the community. In general, the Land Titles Acts of the Provinces of Alberta and Saskatchewan achieve these objectives with respect to ordinary conveyancing matters, but the defects of the said Acts are manifest with respect to problems involved in conveying oil and gas properties and interests therein. One aspect of the problem is the fact that Crown mines and minerals are not under the Land Titles Acts, and as such, an operator must look to the common law and to the legislation under which he acquired the interests to resolve title problems with respect to such oil and gas interests. The first part of this article deals with title problems with respect to Crown mines and minerals; the second part deals with title pro. blems with respect to freehold mines and minerals under the Land Titles Acts. For the oil and gas lawyer who is of the opinion that the common law concept of a bona fide purchaser of the legal estate for value and without notice defeating all equities and the shadowy equities of fraud and fear are proper subjects for the student of legal history, this article points out that these rules are very much alive with respect to Crown mines and minerals, and further points out that if the Supreme Court of Canada follows the Crystallization as opposed to the Registration Theory, as to the effect of a caveat, the said rules will be very much alive with respect to freehold mines and minerals.
\end{abstract}

\section{PART 1: OIL AND GAS PROPERTIES HELD FROM THE CROWN IN ALBERTA AND IN SASKATCHEWAN***}

\section{A. INTRODUCTION}

From its beginning in 1949, Western Canada's modern oil and gas industry has faced a myriad of problems not encountered by any other industry. One problem, peculiar to the acquisition of rights in oil and gas leases or other agreements held from the Crown, is the absence of a system, similar to that provided through the registration of caveats under Land Titles legislation, whereby a contract or other agreement under which rights in an oil and gas lease are acquired can be registered in a government office.

This paper will examine the background of this apparent anomaly and will suggest answers to the questions arising from the following fact situations:

1. X Oil Company is the registered owner of a $100 \%$ undivided interest in an Alberta Crown P. \& N. G. Lease. In January, 1970, it granted to A a $10 \%$ overriding royalty. $A$ is unable to effect registration of his royalty interest under the Alberta Mines and Minerals Act. In March, 1970, X Oil Company sells the lease to $Y$ Oil Company and delivers a transfer thereof to $Y$ Oil Company and the transfer is registered. The solicitors for $Y$ Oil Company examine the files of $X$ Oil Company and find no indication of A's royalty. $Y$ Oil Company is at all times unaware of A's royalty.

(i) Is the interest of $Y$ Oil Company encumbered by A's royalty?

* Peter G. Schmidt, Solicitor, Department of Mines and Minerals, Government of Alberta, Edmonton, Alberta.

** William $\bar{H}$. Bonney, Barrister and Solicitor, Macleod, Dixon, Burns, Love, Leitch, Lomas, Charters and Montgomery, Calgary, Alberta.

*** This portion of the paper was written by Peter G. Schmidt. Part 2, Freehold Oil and Gas Properties in Alberta and in Saskatchewan, was written by William H. Bonney. 
(ii) Would the answer to (i) be different if the lease were a Saskatchewan Crown lease?

(iii) What is the position if $\mathrm{Y}$ Oil Company was otherwise aware of A's royalty even though no disclosure was made by $X$ Oil Company and no reference to it appeared in its files?

(iv) What is the position between $\mathrm{X}$ Oil Company and $\mathrm{Y}$ Oil Company if in the conveyancing documentation, $X$ Oil Company expressly stated that it made no warranty as to title?

2. A Trust Deed affects an Alberta Crown P. \& N. G. Lease. A copy is placed in the Department of Mines and Minerals. The Department issues a letter of receipt, which letter indicates that the indenture is a matter between the parties and will not be otherwise recognized by the Department. What is the effect of this placement?

\section{B. OIL AND GAS PROPERTIES HELD FROM THE CROWN IN ALBERTA}

Provisions for the registration of transfers of and documents pertaining to leases, licences, permits and reservations of petroleum and natural gas rights granted by the Crown in right of Alberta are contained in Part 7 of The Mines and Minerals Act, 1962.1 The effect of Part 7 can be best appreciated by an understanding of its intent as revealed through a brief review of its history and the history of related provisions of the Act and its predecessors.

\section{Historical Development}

Prior to The Alberta Natural Resources Act ${ }^{2}$ almost all mineral rights in Alberta were owned by the Crown in right of Canada. Alberta, of course, emanated out of the North Western Territories (then so called) which were added to Canada in $1870 .^{3}$ The Dominion Lands Act 4 was enacted to apply "except as otherwise provided by any other Act of ... Parliament... to the public lands included in Manitoba and the several territories of Canada." 5 Mineral rights in public lands were administered by the Department of the Interior, and pursuant to the Act could be "disposed of in such manner and on such terms and conditions [as were] from time to time fixed by the Governor General in Council, by regulation made in that behalf." 6 Books were required to be kept in the Department: ${ }^{7}$

... for registering, at the option of the persons interested, assignments of any rights to Dominion lands which are assignable under this Act, upon proof to [the Minister's] satisfaction that such assignments are in conformity with this Act; and every assignment so registered shall be valid against any other assignment unregistered but subsequently registered; but any assignment to be registered shall be unconditional, and all conditions on which the right depends shall be performed, or dispensed with by the Minister before the assignment is registered.

The Dominion regulations under which petroleum and natural gas leases could be acquired provided that "the lessee shall not assign, transfer or sublet the rights described in this lease, or any part thereof, without the consent in writing of the Minister being first had and obtained." 8 This method of acquiring rights from the federal Crown

' S.A., 1962, c. 49.

S.A., 1930, c. 21.

'The British North America Act, 30 and 31 Victoria, c. 3, s. 1.46.

46 Victoria, c. 17 and R.S.C. 18866 , c. 54.

"Id., s. 1.

"Id., 8. 42.

'Id., 8. 76.

"E.g. as contained in section 22 of the regulations under Order in Council dated March 11, 1910, respect. ing the leasing of oil and gas rights. 
and the same procedure for registering assignments were continued in subsequent Dominion Lands Acts ${ }^{9}$ without substantive change. The Acts continued to apply "exclusively to the public lands in ... Manitoba [and to the new Provinces of] Saskatchewan and Alberta and [as well, to] the Territories of Canada."10

Upon the transfer on October 1,1930 , to the Crown in right of Alberta of the natural resources of Alberta, minerals continued to be administered until June 18, 1931, in accordance with the Dominion Lands Act, ${ }^{11}$ the Province having adopted it under The Administration of Natural Resources (Temporary) Act ${ }^{12}$ as though it had been a provincially enacted statute. When the Province passed The Provincial Lands Act ${ }^{13}$ it was made applicable to: ${ }^{14}$

Lands vested in the Crown in the right of the Province by virtue of the agreement of transfer [and to] such other lands as may be vested in the Crown in the right of the Province or any lands vested in the Minister of Municipal Affairs by reason of any statute for the recovery of taxes which shall from time to time be declared by the Lieutenant Governor in Council to be Provincial Lands and subject to the provisions of this Act.

Under the Act, Crown "minerals, together with the right to win, work and get the same [could be] leased in such manner as [was] prescribed by regulations made by the Lieutenant Governor in Council." 15 The Act was administered by the Department of Lands and Mines.

The Act also contained provisions respecting the registration of assignments of any right or interest acquired under it. ${ }^{16}$ As in the Dominion Lands Act, registration was at the option of persons interested and depended on the person not being prohibited by the provisions of the Act, or his lease, licence, permit, conveyance or other instrument from assigning. Registered assignments were also declared to be valid against any other assignment that was unregistered or subsequently registered. Conditional assignments remained unregistrable.

With respect to assignments, the regulations, a copy of which were attached to and by reference incorporated into each lease, provided that: 17

The lessee shall not assign, transfer or sublet the rights described in this lease, or any part thereof, without the consent in writing of the Minister being first had and obtained, and no assignment of such rights shall be accepted and recorded in the Department unless it is unconditional and until all arrears, both as to rental and royalty have been fully paid.

In the lease, the lessee contracted that he would: ${ }^{18}$

... not assign, transfer or sublet the rights described in the . . lease, or any part thereof without the consent in writing of the Minister being first had and obtained, and such consent [would] not be given unless and until all arrears or rent and royalty, interest, penalty or otherwise [had] been paid.

An Act Consolidating The Provincial Lands Act ${ }^{19}$ continued the fore-

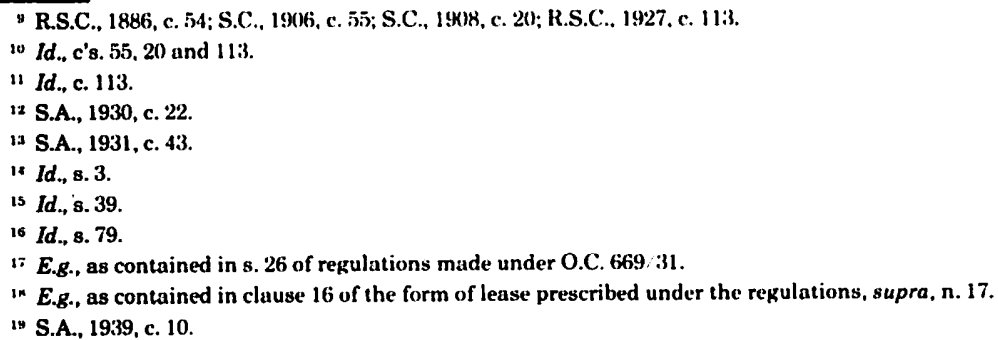


going provisions (in the context of this review) without substantive change. The subsequent revision of the Act ${ }^{20}$ similarly did not change the provisions, although in both cases, "where the context so permitted or required" the application of the Acts was extended "to all lands in the Province," 21 to indicate that certain provisions of the Act, such as those reserving water covered areas to the Province, were of general application and not confined to provincial lands.

When it was found that substantial profits were being derived from assignments of crown lands held under lease, the Province imposed a tax, at the rate of ten per cent, on the increase in value of the interest in the lands over the last preceding value. ${ }^{22}$

Upon the division of the Department of Lands and Mines into the Departments of Lands and Forests and Mines and Minerals, ${ }^{23}$ the new Mines and Minerals Act ${ }^{24}$ charged the latter Department with the responsibility over Crown minerals. The Mines and Minerals Act applied "to all mines, minerals and other related natural resources vested in or belonging to the Crown in right of the Province," and where the context so permitted or required, it also applied "to all mines, quarries and metallurgical works in the Province," thereby indicating the inclusion of provisions of general application such as those relating to safety in the mining and metal industries and to conservation practices relating to oil and gas.

The provisions respecting the registration of assignments were not continued in The Mines and Minerals Act ${ }^{25}$ but were included in The Registration of Assignments of Crown Lands Act, ${ }^{26}$ an Act which was applicable to Crown property administered by three Departments, including the Department of Mines and Minerals, and which Act continued the ten percent incremental tax. When the tax was discontinued,27 the provisions for the registration of assignments of Crown oil and gas leases were returned to The Mines and Minerals Act. ${ }^{28}$

During these adjustments the reference to registration being "at the option of persons interested" was deleted because the permissive phrase "may register" was thought to express with abundant clarity that the same effect still prevailed. Provisions were then added to the Act to permit the registration of assignments under s. 82 of the Bank Act, and for the making of regulations providing for the registration of documents affecting leases, prescribing their form and the conditions under which they could be registered as well as delimiting the effect of their registration in relation to the registration of assignments. ${ }^{29}$

When The Mines and Minerals Act was revised, ${ }^{30}$ the application of the Act was not changed; neither was the procedure for the registration of assignments. The consent of the Minister continued to be

to R.S.A., 1942, c. 62.

21 Supra, n. 19 and 20, s. 3.

22 S.A., 1945, c. 30, 8. 86a.

21 S.A., 1948, c's 2, 3 and 24, and S.A., 1949, c. 34.

is S.A., 1949, c. 66.

25. Kegistration of transfers of certificates of record or mineral claims was provided in 88.125 to 131 ; 8 , 259 required that the consent of the Minister be obtained before an assignment of an oil and gas lease could be effected.

26 S.A., 1949, c. 88.

27 S.A., 1953, c. 75.

2" Id., new Part VIII.

29 S.A., 1955, c. 37.

30 R.S.A. 1955, c. 204. 
required before any assignment, transfer, subletting or parting with the possession of rights held under a lease could be registered.

During all this time assignments registered in the Department came in as many forms as the fertile and unbounded imagination of the solicitors for persons interested, or the persons themselves, could devise. Almost each one differed from the next and all had to be scrutinized with extreme care to assure that it was as unconditional as possible and that the Minister's consent should not be withheld for some other reason such as a deficiency as to form, execution or proof of execution, or too many persons acquiring an interest, or the interests assigned being too small.

When the requirements for the prior consent of the Minister to assignments was discontinued, excepting with respect to parts of the lands granted under a lease, it was also found most advantageous to have a uniform form. A "transfer" was therefore designed and prescribed for use under the Act. ${ }^{31}$ A prescribed form of transfer, of course, continues to date and its use has been found to be equally effective within the framework of the more convenient system of acquiring and holding Crown petroleum and natural gas leases under the present Act. ${ }^{32}$

It may be of interest at this point to mention that at the time of the inclusion of the provisions enabling the making of regulations for the registration of documents affecting leases, ${ }^{33}$ interest in such regulations was only shown by a small portion of the oil and gas industry, while the majority expressed no opinion pro or con and another small portion was strenuously opposed to such regulations, apparently because of a desire to keep the greatest level of confidentiality in relation to its financial tranactions. As a result, no indication ever came forth as to what the content of regulations respecting the registration of documents should be. As a further result, those interested in having regulations, continue, from time to time, to crticize their nonexistence. ${ }^{34}$

2. Historical Effect

The legal effects of being unable to register any instrument affecting a lease, other than a transfer or an assignment under s.82 of the Bank Act become readily discernible when examined in the historic context and present content of The Mines and Minerals Act, 1962.

The key, of course, lies in the nature of the Act. The review has shown that from their inception under federal jurisdiction, the statutes that preceded the Act were statutes that legislated a system of land tenure, limited in application and extent, that is, a system specifying the rules under which tenants of the Crown acquire and hold their interest. Although the methods of acquisition have changed drastically, and the rules of holding have been simplified, the basic purpose of the legislation has not changed. The Mines and Minerals Act, 1962, still prescribes a system of land tenure-unlike The Land Titles Act which is in essence a state guaranteed system providing security of title and facility of transfer and of which was said: ${ }^{35}$

31 S.A., 1957, c. 51, new Part VIII.

32 S.A., 1962, c. 49.

33 Supra, n. 29.

34 E.g., Rae, Oil and Gas Industry Financing, (1969) 7 Alta. Law Rev. 465 at 468-472.

${ }^{35}$ Gibbs v. Messer [1891] A.C. 248 at 254 (per Lord Watson). 
the main object of the Act and the legislative scheme for the attainment of that object appear to be equally plain. The object is to save persons dealing with registered proprietors from the trouble and expense of going behind the register to in. vestigate the history of their author's title and to satisfy themselves of its validity.

In the context of The Mines and Minerals Act, 1962, these objects have also been provided. Firstly, the author's title, that is, the Crown's title is valid. Secondly, when the consent of the Minister to the transfer of all leases became confined to only those instances involving a part of the location, the registration of a lease in the names of more than five persons, or the creation of an undivided interest of less than ten per cent, facility of transfer was assured.

It is recognized that the absence from the Act of provisions for the registration of other interests does retain problems the solution of which appear to be simplified under the Torrens system of Land Titles. As long as The Mines and Minerals Act, 1962, however, remains merely a statute governing a tenure system, it should not be used to change the rights and obligations, inter partes, of persons having privity of contract with the Crown with persons not having privity of contract with the Crown. Therefore the same general observations that have been made about the Torrens system should apply to the system provided by The Mines and Minerals Act, 1962, namely: ${ }^{36}$

It would not be conducive to such security or facility of transfer if a registered owner were not bound by his own contract or if an executor were not compellable by a court to use his registered ownership for the benefit of the person entitled, and accordingly the Acts are to be construed with reference to these purposes and to be taken merely as a part of the general body of law and not superseding it, except by necessary intendment read in the light of the main purposes of the Acts.

In connection with The Mines and Minerals Act, 1962, these comments should be read by substituting "lessee" for "registered owner" and "trustee" for "executor."

Taking this view, our fact situations resolve themselves in accordance with the common law respecting real property applicable in Alberta.

\section{Analysis of Fact Situation}

The expression "common law" in this context must, of course, be read as including "equity" and requires a summary of some of the principles applicable with respect to legal and equitable rights in real property, as follows: ${ }^{37}$

The essential difference between legal and equitable rights is best understood by comparing absolute ownership with trusts... If land was conveyed to $A$ in fee simple upon trust for $B$ in fee simple, the common law courts regarded $A$ as absolute owner and would not recognize any rights in $B$. But the Chancellor would enforce trusts, as matters of conscience, and compel $A$ to hold the land on B's behalf and to allow B to enjoy it. In such a case A is the "legal owner," B is the "equitable owner." The land is vested in A, but since he is trustee of it he is not the beneficial owner: he has only the "bare legal estate," and the beneficial interest belongs to $\mathrm{B}$. Now legal ownership confers rights in rem, rights of property in the land itself, which can be enforced against anyone. Equitable ownership conferred at first only a right in personam, a right to compel the trustee personally to perform his trust. But what should happen if the trustee died or disposed of the land? Trusts would have been hopelessly insecure if means had not been found to protect them from such events. The Chancellors solved this problem by extending the categories of persons upon whom performance of the trust would be en-

36 Thoms, Canadian Torrens System (2nd Ed.), at 176.

37 Megarry and Wade, The Law of Real Property (3rd Ed.), at 118-120. 
joined. As case followed case the extensions became very wide....Two equitable principles explain these developments. First, a person who takes the land without giving value in exchange (such as an heir, executor or donee) must take it with all its burdens, equitable as well as legal: trusts bind volunteers. Secondly, even a person who has given value will be bound if before he obtained the land he knew of the trusts; trusts bind all who take with notice. Both these principles are summed up in the cardinal maxim in which is expressed the true difference between legal and equitable rights:

Legal rights are good against all the world; equitable rights are good against all persons except a bona fide purchaser of a legal estate for value without notice, and those claiming under such a purchaser.

This rule runs right through the law of property; it has been called "the polar star of equity."...Its general meaning is that equitable rights advanced almost to the status of legal rights, but not quite. Equity always stopped short of enforcing a trust against a person who had bought the land from the legal owner in genuine ignorance of the existence of the trust. An equitable owner was therefore never quite in the impregnable position of a legal owner: he never had an absolutely indefeasible title. But the rules relating to notice and the system of conveyancing founded upon them protected equitable interests, as we shall see, for nearly all practical purposes, so that for the sake of their other advantages they were very much used. They became much more than rights in personam against trustees: they were a new species of property right, really rights in rem, but exceptional because of their peculiar infirmity, that they would be lost if the legal title came to a bona fide purchaser without notice. They are therefore commonly called "equitable interests" (sc. in property); for "equity has modelled them into the shape and quality of real estates."

The wide, proprietary character of equitable interests is shown by the modern form of the fundamental rule. Instead of enumerating all the classes of persons bound in addition to trustees themselves, the rule lays down in the first place that equities bind all persons, and then gives a single but very important exception.

From the foregoing it becomes self evident that in dealings involving rights acquired under The Mines and Minerals Act, 1962, or emanating from such rights, the first step in solving any problem arising thereform must be an accurate identification of the nature of the rights involved, i.e., are they legal estates, equitable interests, mere equities or a combination of the same. Once identification has taken place the applicable rules of law and equity should determine the priorities or any other questions involved.

In our fact situation, the petroleum and natural gas "lease" is a profit $\grave{a}$ prendre, ${ }^{38}$ or more particularly, a profit in gross, or "an interest in land which will pass under a will or intestacy or can be sold or dealt with in any of the usual ways, being an incorporeal heriditament" 39 and, of course, a legal estate. If the granting by X Oil Company of the overriding royalty effects the conveyance of a legal estate to $\mathrm{A}$, then $\mathrm{Y}$ Oil Company's subsequent acquisition of the lease will be subject to the royalty, as the maxim nemo dat quod non habet ${ }^{40}$ would apply. If the granting by $\mathrm{X}$ Oil Company of the overriding royalty effects the conveyance of an equitable interest to $A$, then $Y$ Oil Company's subsequent acquisition of the lease will be free and clear of the royalty if in fact $\mathrm{Y}$ Oil Company is a bona fide purchaser of the legal estate for value without notice, all of which elements the eompany is required to prove. ${ }^{41}$

As soon as the appraisal can be made that $\mathrm{Y}$ Oil Company had information respecting the probable existence of A's royalty, the

\footnotetext{
3n Berkheiser v. Berkheiser [1957] S.C.R. 387.

39 Supra, n. 37 at 821.

40 No man can give another any better title than he himself has.

41 Supra, n. 37 at 128.
} 
doctrine of constructive notice or possibly imputed notice would come into operation and the company would take subject to the royalty unless it could prove that it had no such notice.

A purchaser ... has constructive notice of a fact if he -

(i) had actual notice that there was some incumbrance and a proper inquiry would have revealed what it was, or

(ii) deliberately abstained from inquiry in an attempt to avoid having notice, or

(iii) omitted by carelessness or for any other reason to make an inquiry which a purchaser acting on skilled advice ought to make and which would have revealed the incumbrance.

If a purchaser employs an agent, such as a solicitor, any actual or constructive notice which the agent receives is imputed to the purchaser. The basis of this doctrine is that a man who empowers an agent to act for him is not allowed to plead ignorance of his agent's dealings.

Should in this situation any effect be given to the provisions of Part 7 of The Mines and Minerals Act, 1962? That Part, among other things, provides that "upon the registration of a transfer, the transferee becomes the lessee with respect to the agreement . . . ," and "a transfer registered under this Part is valid against and prior to any unregistered transfer." 43 The answer appears to be that the statute would apply only in those instances that fall squarely within its provisions. Firstly, the Crown is given the right to ignore anyone other than the holder of record for the time being of its lease. Secondly, the Crown may not enforce, with some exceptions, ${ }^{44}$ any obligation under the lease against anyone other than its holder of record. The rationale is that anyone wishing to hold rights from the Crown should accept the obligations that attach to such rights by becoming registered in. the Department of Mines and Minerals as a joint tenant in the lease, or as a tenant in common or as its sole tenant. Thirdly, and perhaps of greatest importance, the provisions of section 176(6) have changed the common law in one particular instance. The maxim nemo dat quod non habet has been displayed in favour of certainty of the title of the registered lessee where there is a contest between a prior unregistered transfer and a subsequent registered transfer. As the expression "transfer" is defined, only such contracts or "instruments" as fall within the definition would be affected by the section. An overriding royalty would certainly not be a "transfer."

We therefore find that if the overriding royalty is a legal estate, A would be entitled to payment of the royalty from $Y$ Oil Company when production occurred. Y Oil Company should, for an equivalent amount, or a sum certain in damages, have a right of action against $X$ Oil Company. If the overriding royalty is an equitable interest, $A$ would have a right of action against $X$ Oil Company for an amount equivalent to what the overriding royalty would have been if $X$ Oil Company had remained the lessee and production from the lease had occurred.

If $\mathrm{X}$ Oil Company, in the conveyancing documentation resulting in the execution and registration of the transfer to $Y$ Oil Company, expressly states that it makes no warranty as to title, Y Oil Company, where it has no notice of A's royalty, would be in the same position in relation to $A$ as if the clause were not contained in the documenta-

12 Id., at 127 and 129.

43 S.A., 1962, c. 49, 88. 176(5)(6).

"Id., B. 32. 
tion. It would appear that the courts would not permit X Oil Company to take advantage of its own wrong in failing to disclose $\dot{A}$ 's interest by permitting the company in effect to contract out of such failure. It might even be argued that the principle against the grantor derogating from his grant ${ }^{45}$ would apply. The clause would in this instance be construed against X Oil Company.

Where Y Oil Company had constructive or imputed notice of A's interest, the clause, if anything, should be given its intended effect and construed against Y Oil Company.

In considering the placement of a Trust Deed with the Department the rules respecting actual, constructive or imputed notice must again be examined. There is no requirement, of course, or even provision for the placement in the Department of such instruments. However, any person who is advised by the Department of the existence of the instrument would take the lease to which it relates subject-to the equities contained in the instrument as he would have actual notice.

At the same time, while in the Department, the instrument would not serve as constructive or any other form of notice if the Department did not inform a person inquiring that the deed existed. Presumably, such person would take the lease free and clear of the equities contained in the Trust Deed.

The Department receives Trust Deeds only on the expressed understanding that they will be given effect as a matter between the parties only and that although the Department endeavours to let the grantee know of any notices that are sent out in connection with a lease affected, it does so entirely voluntarily and without undertaking any legal liability to do so or arising as a result of failure to do so.

Since "no man is obliged to accept any assurances made to him or obligation undertaken in his favour without his consent," 46 the Department's disclaimer would appear effectively to release it of any liability to the grantee of the Trust Deed that may result from its failure to notify the grantee of any transaction occuring in relation to the lease affected whereby the grantee's rights thereto could be lost or lessened.

\section{OIL AND GAS PROPERTIES HELD FROM THE CROWN IN SASKATCHEWAN}

Unlike The Mines and Minerals Act, 1962, in Alberta, which despite criticism to the contrary, does provide a fairly complete procedure for the registration of transfers of Crown leases, The Mineral Resources Act ${ }^{47}$ of Saskatchewan employs a slightly different approach and empowers the Lieutenant Governor in Council to make regulations and orders: 48

(b) governing the assignment or subleasing of any rights granted in a disposition of Crown mineral lands;

The regulations containing the procedure for assignments ${ }^{49}$ are somewhat more elaborate in content than Part 7 , but upon close examina-

4s Supra, n. 37 at 816.

46 Halsbury, 3rd Edition, v. 11 at 364 .

17 R.S.S. 1965 , c. 50, s. 10.

48 Petroleum and Natural Gas Regulations, 1969, O.C.8/69.

4y. Id., 8s. 75 to 80 . 
tion do not appear to bring about any different results with respect to registration or registrability than what occurs under Part 7.

An element not provided in Part 7, but contained in the Saskatchewan regulations, is a compulsion to submit for registration to the Department of Natural Resources, which administers the Act and the regulations, any assignment within sixty days of its execution. ${ }^{50}$ This may in itself create problems that do not exist in Alberta; at the same time, the regulations preserve the effect of the document among the parties thereto, despite their failure to submit the document. They then further provide a counterpart to Alberta section 176(6)..$^{51}$ Other differences do exist, such as a general discretion in the Minister to refuse to register any assignment; in Alberta this discretion is, of course, confined to specific cases. ${ }^{52}$ Also no form is prescribed in Saskatchewan.

Provisions for the registration of assignments under section 82 of the Bank Act are included, ${ }^{53}$ as well as a procedure for filing "but not for approval or registration of certain documents such as trust agreements that are in proper form." 54 This in itself would not appear to be different from the Department's practice in Alberta to permit the placement of documents such as Trust Deeds, excepting that the regulations in Saskatchewan give notice that the practice exists. Thus filing of Trust Deeds or similar documents in Saskatchewan would not seem to give any greater security to those filling the instrument than when it is done in Alberta. It is assumed that the expression "trust agreements that are in proper form" refers to agreements that appear not to be for unlawful purposes and that are executed in the normal manner.

We therefore find in Saskatchewan, as in Alberta, a system of registration which is provided as a convenience to those having privity of contract with the Crown, ${ }^{55}$ the only difference again being that the latter Province expresses this intent.

The history of The Mineral Resources Act has the same origin as The Mines and Minerals Act, 1962, and a persual of its provisions indicates that it also continues as a statute designed to provide the rules of tenure from the Crown and not a registration system such as the Torrens Land Titles system. The Petroleum and Natural Gas Regulations follow basically the same evolutionary pattern as Part 7, and although due to the absence of a prescribed form of transfer the regulations may not operate in as simple a manner as Part 7 , they are nevertheless indicative of the same legislative intent, a convenience to Crown tenants.

It would therefore really not be too surprising that a person dealing in both jurisdictions would face basically the same legal problems and most likely in the same set of circumstances would obtain the same judgment in court.

\footnotetext{
so Id., 8. $75(1)$.

S1 Id., s. 79.

32 S.A., 1962, c. 49, s. $176(2)$.

s3 Supra, n. 48, 8. 78.

54 Id., 8. 80(3).

s. Id., 8. 75(4).
} 


\section{CONCLUSION}

For the lawyer who thought that the law of real property as it existed before the Torrens system was mainly a memory in this modern age serving primarily as a part of an education in legal history and in academic exercises, it may be a shock to discover that when dealing with the Crown in respect of oil and gas or other mineral rights, the days of old are fully alive. This may not conjure up visions of knights in shining armour slaying dragons to save damsels in distress, but rather project images of dark courtrooms filled with gowned and wigged barristers arguing that the point His Lordship, the Chancellor on the woolsack had to decide, had to rest on the principle that:56

Where equity is dealing with proprietary interests not recognized at common law, equity applies so far as possible the rules which the common law applies to the corresponding legal interests.

The shock, of course, would come as a result of the sudden realization that "legal estate" may not mean "registered title" and "equitable interest" most certainly does not mean "unregistered interest."

\section{PART 2: FREEHOLD OIL AND GAS PROPERTIES IN ALBERTA AND IN SASKATCHEWAN ${ }^{* * * *}$}

\section{A. INTRODUCTION}

The purpose of this paper is to discuss title problems arising in respect of unregistered and unregistrable interests in freehold oil and gas properties; that is to say, properties to which the Land Titles Act is applicable. An endeavour will be made to draw comparisons between the law in Alberta and the law in Saskatchewan. The subject will be considered in the following order:

(1) The equitable doctrines in the absence of statute;

(2) The Torrens system generally;

(3) Judicial decisions in Alberta and Saskatchewan;

(4) Summary of cases;

(5) Discussion;

(6) Conclusions and recommendations.

It may be of assistance to the reader to consider the following sample problem when reading the paper:

$A$ is the lessee under a freehold petroleum and natural gas lease. $A$ has filed a caveat protecting his lease. A acquired this lease jointly for himself and B, each as to a 50\% interest, and $\mathrm{A}$ has written a letter to $\mathrm{B}$ in which he acknowledges that a $50 \%$ interest is held in trust for B. B does not file a caveat. A forgets about, or ignores, B's interest and enters into a farmout agreement with C, without B's knowledge or consent, agreeing to grant to $\mathrm{C}$ a $100 \%$ undivided interest in the lease in exchange for the drilling of $a$ well and a royalty reserved. $C$ is unaware of B's interest and files a caveat claiming an interest under the farmout agreement. Prior to drilling the well, $\mathrm{C}$ causes his solicitors to conduct a title investigation of A's interest. A's agreement file contains only the lease and there is no reference therein to $B$ 's interest. There is a letter on A's correspondence file which reflects the interest of $B$, but $A$ does not offer the file and C's solicitors do not ask for it. The farmout agreement from $A$ to $C$ contains a titles clause which negates any warranty of title by A. C drills the earning well and earns his interest, and A gives an assignment of the lease to $\mathrm{C}$. The well is completed as a producing oil well with an initial rate of flow of 1,000 barrels per day. B then learns of the farmout to $\mathrm{A}$ and files a caveat claiming a $50 \%$ interest in the lease. Shortly thereafter

-... This portion of the paper was written by William H. Bonney.

in Ashburner, Principles of Equity at 65. 
$C$ files his caveat protecting his assignment of the lease. B claims a $50 \%$ interest in

the lands. C claims priority over B's interest.

This is only one example of the situation which can arise and one can easily imagine a number of variations to the above situation. Suppose $C$ had not filed a caveat based on the farmout agreement. Suppose that $B$ did not file his caveat until after $C$ had filed a caveat based on the lease assignment. Following the discussion of the law this sample problem shall be discussed in more detail.

\section{B. THE LAW IN THE ABSENCE OF STATUTE}

1. Qui prior est tempore potior est jure

In Boulter-Waugh \& Co. Ltd. v. Phillips, Haultain, C.J.S. observed in the Court of Appeal decision: ${ }^{57}$

The legal rule nemo dat qui non habet [he who hath not cannot give] applies to persons entitled to equitable interests in the same property, and the purchaser or mortgagee for value of an equitable interest with notice takes subject to all other equitable interests preceding in point of time the interest he acquires. Qui prior est tempore potior est jure [first in time is first in law].

Mignault, J. in the Supreme Court of Canada referred to the above statement by Haultain, C.J.S. as follows: ${ }^{58}$

The learned Chief Justice of Saskatchewan cites certain maxims coming, I think, originally from the Roman Law with which, as a civilian, I am familiar, such as nemo dat qui non habet, or qui prior est tempore potior est jure. But I may say with deference that these maxims are not of universal application, and when third parties are concerned they cannot be applied without some qualification. It might, moreover, be possible to offset axiom by axiom and to refer to the one so often mentioned by the old jurists, vigilantibus non dormientibus scripta est lex [the law is written for the vigilant, not for the sleepy].

It is at once apparent from the foregoing that questions of equitable priority will not be resolved by the application of trite phrases, but recourse must be had in all cases to the facts. Accordingly, it will be extremely difficult to set forth principles which when applied will answer all questions in all situations. An outline of the law in this regard will assist in our considerations.

While the legal estate is outstanding, the priority of competing equitable interests is prima facie governed by the rule qui prior est tempore, potior est jure. Two views have been put forward of the principle upon which the court should act when it is called upon to determine rights as between rival equitable claimants.

One is that in a contest between rival equities priority of time is the last consideration which should be resorted to. The question which of two or more contending equities has the better or best equity depends (according to this view) primarily upon the conduct, whether by act or omission, of each equitable claimant in relation to the other or others. Where all are equally innocent, where no one has been guilty of negligence, misrepresentation or fraud, which has induced the creation of another equitable title, where no one has taken with knowledge or notice of another equitable title, then, for want of a better criterion, the court is obliged to determine their priority by the order in time at which their titles arose. This is the view of Kinder-

\footnotetext{
$\therefore$ [1918] 3 W.W.R. 27 at 28.
}

in (1919) 58 S.C.R. 385 at 402. 
sley, V. C. in Rice v. Rice ${ }^{59}$ and Anglin, J. in McKay v. McDougall.60

The other view, which is supported by the great mass of authority, is that the priority of equitable titles as between themselves is determined prima facie by the priority in time of their creation; but that this priority may be displaced by acts or omissions on the part of an earlier equitable claimant. Turner, L.J. said in Cory v. Eyre: ${ }^{61}$

Questions of priority between equitable incumbrancers are in general governed by the rule que prior est tempore potior est jure, and in determining cases depending on the rule we must of course look at the principle on which the rule is founded. It is founded, as I conceive, on this principle, that the creation or declaration of a trust vests an estate and interest in the subject matter of the trust in the person in whose favour the trust is created or declared. Where, therefore, it is sought ... to postpone an equitable title created by declaration of trust, there is an estate or interest to be displaced. No doubt there may be cases so strong as to justify this being done, but there can be as little doubt that a strong case must be required to justify it.

The normal priority of equitable claimants may be displaced by an application of the doctrine of estoppel. If the owner of the prior equitable title by conduct or by negligence induces a person to change his position and to acquire for valuable consideration a title later in time in the belief that there is no earlier title, he is estopped, as against that person, from setting up his prior equitable title. ${ }^{62}$

\section{Notice-Actual and Constructive}

The plea of purchaser for value without notice is looked upon with favour in equity. When there is an existing equitable interest in property, and an interest is subsequently created in favour of a purchaser for value without notice of the earlier interest and that purchaser gets in the legal estate at the time of his purchase, or, in certain circumstances, after his purchase, his possession of the legal estate gives him priority over the earlier equitable owner. ${ }^{63}$ Where a purchaser does not get in the legal estate at the time of his purchase, he may get in the legal estate subsequently and gain priority over earlier equitable interests of which he had no notice at the time of his purchase, but this is subject to the qualification that where the earlier equitable interest is a trust of the legal estate, the purchaser who gets in the legal estate after notice of the trust, cannot avail himself of the legal estate as against the prior equitable interest. By taking a conveyance with notice of the trust he himself becomes the trustee. ${ }^{64}$

It is apparent, therefore, that once the legal title is in, then in the absence of fraud and with the exceptions noted above, the rule qui prior est tempore, potior est jure is no longer applicable and the owner of the legal title can only be attacked on the basis that he is not a purchaser for value without notice. ${ }^{65}$ Notice of a prior dealing which will defeat a plea of purchaser for value without notice may be either actual or constructive.

For actual notice to be binding it must be given by a person interested in the property and in the course of the negotiation. ${ }^{66}$ Where notice is

${ }^{19}(1853) 2$ Drew. 73, 61 E.R. 646.

nat [1922] 3 W.W.R. 191 at 195.

i1 (1863) 1 De G.J. \& S. 149, 46 E.R. 58 at 65.

62. Phillips v. Phillips (1862) 4 De G.F. \& J. 208, 45 E.R. 1164, per Lord Westbury at 1167.

6i: Marsh v. Lee (1670) 2 Vent. 337, 86 E.R. 473; Pilcher v. Rawlins (1872) 2 Ch.App. 259.

it Taylor v. Russell [1892] A.C. 244 at 253.

(i) Dodds v. Hills (1865) 71 E.R. 528.

* Barnhart v. Greenshields (1853) 9 Moo P.C. 18, 14 E.R. 204. 
given to a corporation it must be given to an official as such. ${ }^{67}$ But it has long been established that notice to an agent (such as a solicitor) who is employed in a transaction of purchase is notice to his principal.68 In England under the Land Charges Act, 1925, registration in the register is deemed to constitute actual notice by virtue of the provisions of the statute. There is no such provision in the Alberta Land Titles Act, but the effect is the same. ${ }^{69}$

The doctrine of constructive notice is conveniently summarized in Ashburner's Principles of Equity ${ }^{70}$ as follows: ${ }^{71}$

The cases on constructive notice, so far as they are to be treated as law, fall under one or other of the following heads:

1. A purchaser who does not either personally or by his agent make the investigation of title which is usual, having regard to the nature of the property which he is purchasing, is affected with notice of whatever he or his agent would have found out if the usual investigation of title had been made;

2. A purchaser who either personally or by his agent has notice of circumstances which in fact affect the property the subject matter of his purchase and which may be explained on several legal hypotheses takes the risk, if he makes no further inquiry, of that hypothesis being true which is most contrary to his interest.

It is immaterial by what motive a purchaser is activated who neglects either to make the usual inquiries or to pursue a course of investigation which has been opened out. He is equally affected with notice whether his abstinence from in quiry arises from negligence or from mala fides. Each of these heads requires explanation.

... Generally speaking, a purchaser of land is bound to inquire into his vendor's title, and is affected with notice of what appears on the title if he does not inquire... A purchaser is entitled to assume that the abstract of title which his vendor communicates contains all the deeds and documents which are material. If the deeds abstracted offer a complete chain of title for the period which, by custom or by statute, the purchaser is bound to investigate, the purchaser is not affected by notice of a deed which is neither recited in these deeds nor referred to in the conveyance. ${ }^{72} \ldots$

...As regards the second head of constructive notice, it is only possible to give a few illustrations out of the vast mass of decided cases.

Knowledge of a deed which necessarily affects the land is notice of the contents of that deed and of all other deeds to which it refers as affecting the land. ${ }^{73} \mathrm{Know}$ ledge that property is subject to a trust is notice of all the terms of the trust. ${ }^{74}$ On the other hand, knowledge that the draft of a deed has been prepared is not notice that the deed has been executed..$^{75}$

A man who purchases property where a visible state of things exists which could not legally exist unless the property was subject to some burden, has notice of the extent and nature of the burden.

The possession or receipt of the rents and profits of land by a person other than the mortgagor or vendor is a fact which necessarily affects the land; but the degree in which it affects the land can only be ascertained by further inquiry; and a purchaser who knows that some person other than his vendor or mortgagor is in possession or reciept of the rents and profits has constructive notice of the interest, whatever it may be, of that person. ${ }^{6}$

"i Simpson v. Molsons' Bank |1895| A.C. 270 (J.C.P.C.).

no Marjoribanks v. Hovenden (1843) Dru. t. Sugd. 11.

is Imperial Oil Ltd. v. Conroy (1954) 12 W.W.K. (NS) 569, per McBride J. at 574.

i" Second Edition.

"Supra, n. 14 at $62-66$.

:2 Carter v. Williams (1870) L.R. 9 Eq. 678.

$\therefore$ Bisco v. Earl of Banbury (1676) 1 Ch.Cas. 2x7; Moore v. Bennett (1678) 2 Ch.Cas. 246; Coppin v. Fernyhough (1788) 2 B.C.C. 291.

"Anon., Freem. Ch. 137; Malpas v. Ackland (1627) 3 Kuss. 273; Perham v. Kempster [1907) 1 Ch. 373.

$\because$ Cothay v. Sydenham (17*8) 2 B.C.C. 391.

is Knight v. Bou'ver (1858) 2 De G. \& J. 421 ; Hunt v. Luck 1902) 1 Ch. 428. 
It has even been held that possession by a tenant gives constructive notice that the tenant holds under a lease containing a covenant for renewal, ${ }^{77}$ or that he has an equitable agreement for the sale to him of the property; ${ }^{78}$ but it does not give constructive notice of the rights of any person through whom the tenant claims. ${ }^{79}$ On the other hand, knowledge that property has been in the possession of a person other than the vendor is not knowledge of a fact which necessarily affects the property; and a purchaser is not affected with notice of what that person's interest was.

On the same principle knowledge that the title deeds of land are not in the possession of the vendor or mortgagor or of some person who holds them merely as his agent but of a stranger is knowledge of a fact which necessarily affects the land, and is therefore notice of the rights, whatever they may be, of the person in whose possession they are.

But actual knowledge that the title deeds are not in the hands of the vendor or mortgagor when inquiry is made for them, is not necessarily notice that they are in the possession of a stranger. It is not notice if the purchaser has made inquiry for the deeds and has received a reasonable excuse for their nondelivery or nonproduction. Therefore a mortgagee was held not to have notice that the deeds were out of the mortgagor's possession (and in consequence not to have notice that they had been deposited to secure a debt) where the mortgagor promised to bring them in a few days, ${ }^{82}$ where he said on a mortgage of a lease that he would look for the lease and give it to the mortgagee when he next came to market, ${ }^{83}$ or where he said that he had mislaid the lease but would look for it and hand it to the mortgagee. ${ }^{84}$ On the other hand, a purchaser who makes no inquiry for the title deedswho does not even ask to have them delivered, ${ }^{85}$ or (if he is told that they relate to other property) to have them produced ${ }^{86}$ is deemed to have notice that they are in the possession of a stranger, and consequently to have notice of the stranger's rights whatever they may be.

Where a purchaser has notice of a legal burden affecting the land, but the nature or extent of the burden is incorrectly or insufficiently stated, the purchaser has notice of the truth. ${ }^{\mathrm{k}} \mathrm{r}$

A purchaser may know a fact which may or may not affect the property sold-a fact which, in some cases probably, in others possibly, affects the subject of his purchase.

The duty of a purchaser, and his liability if that duty is neglected, varies with the greater or less probability of the fact which he knows affecting the property sold, and with the extent of the investigation which he has made for the purpose of ascertaining the truth. ${ }^{\mathrm{s}}$

In Jones v. Smith ${ }^{\text {s9 }}$ an intending mortgagee inquired of the mortgagor and his wife whether any settlement had been made on their marriage, and was informed that a settlement had been made, but that it did not include the husband's estate. It was held that he was not affected with notice that the property mortgaged was in fact comprised in the marriage settlement.

If the fact which may or may not affect the property sold took place a long time

iT Taylor v. Stibbert (1794) 2 Ves. jun. 437.

in Daniels v. Davison (1811) 16 Ves. 249; 17 Ves. 4333.

is Hunt v. Luck [1902] i Ch. 428.

*o Miles v. Langley (1829) I R. \& M. 39.

"1 Birch v. Ellames (1791) 2 Anst. 427; Hiern v. Mill (1801) 13 Ves. 114; Dryden v. Frost (1838) My. \& Cr. 670.

N2 Plumb v. Fluitt (1791) 2 Anst. 432

n. Hewitt v. Loosemore (1851) 9 Ha. 449.

n4 Espin v. Pemberton (1859) 3 De G. \& J. 547. See also Brou'n v. Stedman (1896) 44 W.R. 458.

"Worthington v. Morkan (1849) 16 Sim. 547; Maxfield v. Burton (1873) LR. 17 Eq. 15; Berwick \& Co. v. Price [1905] I Ch. 632.

us Peto v. Hammond (1861) 30 B. 495; Oliver v. Hinton (1899) 2 Ch. 264; and cf Hudston v. Viney [1921] 1 Ch. 98.

ni Taylor v. Baker (1818) 5 Pri. 306; Jones v. Williams (1857) 24 B. 47; Montefiore v. Browne (1858) 7 H.L. Cas. 241.

nN English and Scottish Mercantile Investment Co. v. Brunton [1892] 2 Q.B. 700.

49 (1841) I Ha. 43; (1842) I Ph. 244. A purchaser would now be entitled to nssume without inquiry that, if a marriage settlement was not included in the abstract furnished to him, it did not affect the property purchased. | Patman v. Harland (1881) 17 Ch. D. 3533 at :357). 
ago and the claim which would have existed if the fact had affected the property has never been made, the purchaser is entitled to assume that no such claim exists.

\section{THE LAND TITLES SYSTEM}

1. Purposes

Generally speaking, the main object of the land titles system is to protect a transferee in good faith and for value. The best known statement of the intention of the land titles system is the passage by Lord Watson in Gibbs v. Messer referring to the State of Victoria Act:90

The main object of the Act, and the legislative scheme for the attainment of that object, appear to them to be equally plain. The object is to save persons dealing with registered proprietors from the trouble and expense of going behind the register, in order to investigate the history of their author's title, and to satisfy themselves of its validity. That end is accomplished by providing that every one who purchases, in bona fide and for value, from a registered proprietor, and enters his deed of transfer or mortgage on the register, shall thereby acquire an indefeasible right, notwithstanding the infirmity of his author's title.

In Kaup v. Imperial Oil Ltd.91 Martland, J. referred to this statement by Lord Watson and said of the Alberta Land Titles Act:92

The sections of the Act dealing with the position of the bona fide purchaser for value, which I have mentioned, support these views as to the purpose and intent of the Act. The fact that these provisions were incorporated in the statute negatives the suggestion that the Act further curtails the old common law rule that no man can convey a better title than he possesses, so as to enable a transferor, having no title at all, to vest in a volunteer a legal title valid as against the true owner. In my opinion, the Land Titles Act altered that rule only to the extent that it established certain special rights for the benefit of the bona fide purchaser for value. ${ }^{93}$ [Italics added].

\section{Unregistered and Unregistrable Interests-Caveats}

It is appropriate to consider at this time the nature of unregistered and unregistrable interests. It is well known that certain instruments are themselves susceptible of registration on the register if they are in proper form; for example, transfers, leases, mortgages, easements. Other documents are registrable by virtue of the provisions of other statutes; for example, mechanics' liens, tax notifications and the like.

In certain circumstances an instrument otherwise registrable may become unregistrable. A mortgage or a transfer is unregistrable if the duplicate certificate of title to the subject property has been previously hypothecated by a pledge of title deeds. A lease may be unregistrable because it is not in proper form as required by the Act, although otherwise enforceable. An unregistered interest is presumably either an interest pursuant to an instrument which is registrable but has not been submitted for registration or an interest pursuant to a document which is not by its nature registrable. It has been held that all unregistered interests are merely equitable interests..$^{94}$

If an interest is derived pursuant to an unregistrable instrument, such interest may be protected by filing a caveat. Caveats may also be filed for registrable instruments. Section 136 of the Act sets forth who may file caveats under the system. Although it is possible for

\footnotetext{
$\$$ [1891] A.C. 248 at 254.

11 (1962) 37 W.W.R. 193 at 207.

92 S.A. 1906, c. 24, although comments equally applicable to present Act; R.S.A. 1955, c. 170. For the remainder of this paper references to the Act or the Alberta Act are references to the present act as amended.

93 See also Assets Co. v. Mere Roihi [1905] A.C. 176, and Brown v. Broughton (1915) 24 D.L.R. 244 at 252.

ot Stephens v. Bannan and Gray (1913) 5 W.W.R. 201 at 210 (Alberta Court of Appeal) (per Beck, J.).
} 
the lessee under a petroleum and natural gas lease to register the same and obtain a certificate of title to a leasehold interest, this is not usual procedure in the industry. ${ }^{95}$ Leasehold and other interests in mineral properties are customarily protected by filing caveats. Section 136 provides that "any person claiming to be interested under any.... instrument of transfer... or under an unregistered instrument, ...or otherwise howsoever in any land, mortgage or encumbrance, may cause to be filed... a caveat...." Accordingly, it is clear from Section 136 that if the interest concerned is an interest in land or an encumbrance on land, then such interest will support the registration of a caveat in respect thereof.

The words "or otherwise howsoever" are not restricted to a claim which is evidenced by some instrument or document in writing. ${ }^{96}$ The word "interest" is intended to have the widest interpretation under the Acts. In C.P.R. v. District Registrar of Dauphin Land Titles Office Tritschler, J. said: ${ }^{97}$

The Act does not require that the caveator shall claim to have an estate or interest in land which is derived from the registered owner nor does it empower the district registrar to decide whether a claim asserted by a caveator is binding upon or enforceable against the registered owner.... It is trite law that caveats are to be used for the protection of alleged as well as of proved interests and that a caveat is merely a warning which creates no new rights but protects existing rights, if any.

Section 152 of the Alberta Act sets forth the effect of registration by way of caveat. No such provision appears in the Saskatchewan Act.

152. Registration by way of caveat, whether by the Registrar or by any caveator, has the same effect as to priority as the registration of any instrument under this Act, and the Registrar may in his discretion allow the withdrawal of a caveat at any time and the registration in lieu thereof of the instrument under which the person on whose behalf the caveat was lodged claims his title or interest, if the instrument is an instrument that may be registered under this Act, and, if the withdrawal of the caveat and the registration of the instrument is simultaneous, the same priority is preserved to all rights under the instrument as the like rights were entitled to under the caveat.

Section 152 gives the registration by way of caveat the same priority as registration of any instrument under the Act. Section 58 provides that "Instruments registered in respect of or affecting the same land have priority the one over the other according to the time of registration and not according to the date of execution."

At one time a strong view prevailed that there was no such thing as an unregistered or equitable interest in land under the Torrens system, and that the Land Title Act created a new interest, the registered interest, to take the place of the old legal estate. Some support to this view can be found in the provisions of Section 56 of the Act which provides:

56. After a certificate of title has been granted for any land, no instrument is effectual to pass any estate or interest in that land (except a leasehold in. terest for three years or for a less period) or to render that land liable as security for the payment of money, unless the instrument is executed in accordance with the provisions of this Act and is duly registered thereunder, but upon the registration of any such instrument in the manner hereinbefore prescribed the estate or interest specified therein passes or, as the case may be, the land becomes liable as security in manner and subject to the covenants,

95 Imperial Oil Ltd. v. Conroy (1954) 12 W.W.R. (NS) 569 at 574.

9 Re MacCullough and Graham [1912] 2 W.W.R. 311.

${ }^{97}$ (1956) 18 W.W.R. 241 at 243.244. 
conditions and contingencies set forth and specified in the instrument or by this Act declared to be implied in instruments of a like nature.

The definition of "instrument" in Section $2(j)$ does not specifically include a caveat but refers to "any document relating to...land," and this language would on any liberal interpretation include a caveat. Thus it can be argued that Section 56 prohibits the existence of unregistered interests in land. It was this that led Anglin, J. to observe in the Supreme Court of Canada decision in Bank of Hamilton v. Hartley ${ }^{98}$ that, where a statute provides that no interest in land shall be recognized at law or equity until registered, the idea that unregistered interests may exist is "quite too subtle to follow." There can be no doubt, however, that equitable and unregistered interests in land do exist under the system and will be recognized by the courts.99 In Church v. Hill ${ }^{100}$ Anglin, J. said:

The result of decisions of this court in Jellett v. Wilkie [1896] 26 S.C.R. 282, Williams v. Box [1910] 44 S.C.R. 1, Smith v. National Trust Co. [1912] 45 S.C.R. 618, Yockney v. Thomson [1914] 50 S.C.R. 1, Grace v. Kuebler [1917] 56 S.C.R. 1, and other cases, is that, notwithstanding such provisions as Sec. 41 of ch. 24 of the Alberta statutes of 1906, equitable doctrines and jurisdiction apply to lands under the land titles or Torrens system of registration and equitable interests in such lands may be created and will be recognized and protected.

In fact the Act itself speaks of unregistered interests. Section 203 provides as follows:

203. Except in the case of fraud, no person contracting or dealing with or taking or proposing to take a transfer, mortgage, encumbrance or lease from the owner of any land in whose name a certificate of title has been granted shall be bound or concerned to inquire into or ascertain the circumstances in or the consideration for which the owner or any previous owner of the land is or was registered or to see to the application of the purchase money or of any part thereof, nor is he affected by notice direct, implied or constructive, of any trust or unregistered interest in the land, any rule of law or equity to the contrary notwithstanding, and the knowledge that any trust or unregistered interest is in existence shall not of itself be imputed as fraud.

\section{Effect of the Register}

A question which arises is whether under the Alberta and Saskatchewan Acts, the legislation intends to extend or in fact extends to a party not dealing with the registered owner the same protection granted under Section 203 of the Act reproduced above to persons dealing with the registered owner.

It is clear from the Act and the cases that a party dealing with the registered owner who either registers the instrument itself or protects his interest by way of caveat, is entitled to the protection afforded by the Act. Thus if $A$ takes a petroleum and natural gas lease from the registered owner and files a caveat protecting his interest under the lease, he is unaffected by the existence of a petroleum and natural gas lease which is unregistered or in respect of which no caveat has been filed even though such unregistered lease was granted prior in time, and $\mathrm{A}$ was aware of the same. This appears to be the clear intention and effect of Section 203.

YN [1919] 1 W.W.R. 868 at 873 .

99 Wilkie v. Jellett (1895) 2 Terr. L.R. 133; affd. 26 S.C.R. 282; Bank of Hamilton v. Hartery [1919] 1 W.W.R. 868; MaDougall v. MacKay (1922) 64 S.C.R. I at 11; McKillop and Benjafield v. Alexander (1912) 45 S.C.R. 551.

tow [1923] S.C.R. 642 at 644. 
Lord Wright in delivering the judgment of the Judicial Committee in Lapin v. Abigail in referring to the Torrens system said:101

... It is a system for the registration of title, not of deeds; the statutory form of transfer gives a title in equity until registration, but when registered it has the effect of a deed and is effective to pass the legal title; upon the registration of a transfer the estate or interest of the transferor as set forth in such instrument with all rights, powers and privileges thereto belonging or appertaining is to pass to the transferee. No notice of trusts may be entered on the register book but it has long been held that equitable claims and interests in land are recognized under the Real Property Acts.

Thom's Canadian Torrens System (following a reference to the above statement by Lord Wright) states:102

But a person who has acquired a merely equitable interest cannot rely on the protection given by the Act to those who deal with the registered proprietor. Such a person is left to such rights as he can establish on general principles of equity. Thom relies on Australian decisions ${ }^{103}$ to support this proposition. The Australian cases may decide the question with respect to those jurisdictions in Australia to which the cases referred to above apply. But do they decide the matter under the Alberta and Saskatchewan Acts?

The Alberta Land Titles Act (and the Manitoba Land Titles Act, although we are not considering that Act in this paper) contains language which is not present in the Australia Act, or for that matter in the Saskatchewan Act. I refer to the provisions of Section 152 of the Alberta Land Titles Act set out above, to the effect that registration by way of caveat has the same effect as to priority as the registration of any instrument under the Act. In Manitoba the filing of a caveat has this effect. Most Torrens systems do not refer to the "registration" of a caveat, but to the "filing" of a caveat, and do not contain language similar to Section 152 of the Alberta Act. Accordingly, it can be argued that under the Alberta Act registration of a caveat provides the caveator with the same protection as a grantee under any instrument capable of registration under the Act.

The question has received a most excellent and detailed treatment in Thom's Canadian Torrens System, ${ }^{104}$ with respect both to the law of Alberta and Saskatchewan and has received treatment in other articles as well. ${ }^{105}$ There is little point to reproducing in this paper the lengthy discussion therein set forth, but as the above authority may not be available to all who read this paper and as the inferences to be drawn from the cases are not entirely conclusive, I shall refer to the more important decisions.

\section{JUDICIAL DECISIONS}

\section{The Law in Alberta}

The first case of importance to consider the matter was Stephens v. Bannan and Gray $y^{106}$ in the Alberta Court of Appeal. The facts of the case are important as in this case the competing claimants were

\footnotetext{
III' [1934] 3 W.W.R. 689 at 694.

1112 Thom's Canadian Torrens System 171 (2d ed. DiCastri 1962).

1'. Davies v. Ryan (1951) V.L.R. 283: following Templeton v. Leviathan Property Ltd. (1921) 30 Comm. L.R. 34 at 54; Butler v. Fairclough (1917) 2:3 Comm. L.R. 78 at 91.

Iil4 Thom, supra. n. 45.

11i: See Case and Comment, (1950) 28 Can. Bar Rev, 456, and also (1924) 2 Can. Bar. Rev. 327 at 331

114 (1913) 5 W.W.R. 201.
} 
claiming under documents which could not be registered and were not granted by the registered 'owner. The Hudson's Bay Company sold Lot 178 to Stephens on an agreement for sale dated in 1905. By assignment dated July 25, 1906, Stephens assigned his agreement for sale to Dodge and Goldsmith. This transaction had evidently been arranged some time before, for by instrument dated June 1, 1906, Dodge and Goldsmith agreed to sell Lot 178 to Lloyd. By instrument dated March 18, 1911, Lloyd agreed to sell to Gray the same Lot 178 . On November 16, 1911, Gray filed a caveat against the lot in question claiming an interest as purchaser under the latter agreement. The title to Lot 178 was still registered in the name of the Hudson's Bay Company as the balance owing on the agreement for sale had not been paid. Stephens died in 1907 leaving a will whereby he bequested his entire estate to his sister, Miss Stephens. Advertisement for creditors was published and the estate promptly wound up by the executors and Miss Stephens became entitled to all remaining assets of the estate including, so far as then appeared, Lot 178. In October, 1910, the Hudson's Bay Company demanded payment of the balance of purchase monies under the agreement for sale and Miss Stephens paid the same. On February 11, 1911, believing herself absolutely and beneficially entitled to Lot 178, and Gray's caveat not having been filed, Miss Stephens agreed to sell the lot to Bannan by instrument of that date. On December 21, 1911, just over a month after Gray's caveat was filed, Bannan filed a caveat claiming an interest as purchaser under her agreement with Miss Stephens. On December 29, 1911, Miss Stephens, having been paid by Bannan, obtained an abstract of the title through her solicitors for the purpose of sending it to the Hudson's Bay Company with her request for a transfer. No transfer had previously been requested because there was no urgency in the matter. It was then for the first time that Miss Stephens had notice of Gray's caveat. The executors had never had any notice of an adverse claim to the lot, nor had Bannan. The lot had never been occupied or improved. The court had to decide whether Bannan or Gray was entitled to the lot in question.

Beck, J. with Simmons, J. concurring found in favour of Gray. As the decisions in the case set forth the two sides of the agrument with great clarity, I reproduce the same at length. ${ }^{107}$

Under the decision of the Supreme Court of Canada [referring to Alexander v. McKillop and Benjafield [1911] 1 W.W.R. 871] it seems settled that apart from a provision to the effect of $\mathrm{s} .97$ [now 152] of the Alberta Land Titles Act, where two caveats are lodged the first caveator does not necessarily acquire priorityhis claim may by his laches and the greater carefulness of the second caveator be postponed to that of the latter; for instance of two persons who obtained agreements for sale from the registered owner if the second in point of time paid his full purchase money and obtained a transfer which he could not register by reason of his not being able to obtain possession of the certificate of title he would no doubt be held to have priority over the first caveator because his title was the stronger. But under the Alberta Land Titles Act in view of 8.97 it seems to me the result would be different; that of two innocent persons claiming under equitable titles-and all unregistered interests are merely equitable interests-the one who first lodges a caveat secures priority. The claim of each caveator must of course be grounded immediately or mediately upon a dealing with the registered owner, and the two caveats must claim to affect in whole or in part the same interest in the land. Fraud of course would vitiate the claim of either... Fraud affects the question of the validity of the claim. Notice affects the question not of its validity, 
but solely of its priority. So with the question of laches or vigilance. [Italics added]. Section 97 deals explicitly with priorities and hence in my opinion embraces cases where notice, laches, or vigilance would otherwise be important questions for consideration.

The result in my opinion is that as between the claims of two caveators the section fixes the priorities of the claims according to the dates of the lodging of the caveats so that the only questions that can be open between the two caveators are (1) whether the respective dealings with the land-were it not for the other-created an interest, and that in the same interest in the land and (2) whether the claim of either of the caveators is voided by fraud.

In my opinion, therefore, for the reasons I have stated the claim of Gray, he hav. ing lodged his caveat first, is entitled to priority-even though at the time of doing so he may have had notice of the prior equitable interest of Mrs. Bannan or her predecessors in title, and notwithstanding any laches that may be attributed to him or his predecessors in title or the greater vigilance and activity of Mrs. Bannan and her predecessors in title.

The other side of the argument was taken by Stuart, J. (Walsh, J. concurring). He found on the facts that Gray had the right to call for a conveyance and then stated:108

This makes it strictly unnecessary for me to deal with the question of the caveats. But I think it right to say that I cannot at present accept the view of the effect of s. 97 in our Land Titles Act which is presented in the judgment of my brother Beck. The section is obscure. It says:

'Registration by way of caveat, whether by the Registrar-or by any caveator shall have the same effect as to priority as the registration of any instrument under this Act.

The expression 'registration by way of caveat' suggests the question, 'registration' of What? Does it mean the registration of some otherwise unregistrable interest by means of the filing of a caveat? If Parliament meant to enact that a person having an interest unregistrable under any other provision of the act might register that interest by filing a caveat under s. 84 it would have been very simple to say so. It is well known that the particulars of the interest claimed do not need to be shown in the caveat but only its general nature. S. $85,{ }^{109}$ and Alexander v. McKillop et al 45 S.C.R. 551 at p. 580 . Usually under registry acts the idea of registering a document is to give the public notice of it as well as an opportunity of examining its contents and terms.

The expression 'registration by way of caveat' does indeed seem to suggest that the draughtsman had in his mind the idea of registration of something other than the caveat. But the use of such an obscure term without anything in the foregoing clauses to suggest the same idea cannot in my opinion affect the meaning of s8. 84 and 85 which provide, not in so many words for registering certain interests, but merely for the filing of a caveat:

'against the registration of any person as transferee or owner of or of any instrument affecting such estate or interest unless such instrument be expressed to be subject to the claim of the caveator.'

The clause I quote evidently means that another person may become registered owner in the face of the caveat provided his certificate is expressed to be subject to the claim of the caveator, and we know that this is sometimes done in practice. Does this not mean 'subject to the claim as it existed immediately prior to the filing of the caveat,' or can it possibly mean subject to that claim plus something else? Surely the 'claim' of the caveator means his claim when he proceeds to file his caveat and not anything more.

Again, I am afraid of the results of the interpretation given by my brother Beck. S. 84 says that a person claiming under a will may file a caveat. Then suppose $A$ gives B an agreement of sale of certain lands either before or after having devised them in his will to $C$, and dies. Then suppose $C$ files a caveat as claiming under the will. Does he get priority over B? If the suggested interpretation be correct, why not? The fact that a will speaks only from death does not differentiate the case because an agreement of sale can only speak from the date of its execution,

11' Id., at $204 \mathrm{ff}$

1199 Ss. 84 and 85 referred to are now ss, 136 and 137 in R.S.A. 1955, c. 170. 
and if in the one case there was nothing for the will to act upon then what is there for a second agreement of sale to act upon so as to give a caveat the power of creating effectiveness in it as against a prior agreement of sale?

Furthermore, s. 97 says that registration by way of caveat shall have the same effect as to priority, etc. The question is 'as to priority' of what? It would have been quite easy to say 'of the interest claimed' but those words are not there. Surely the priority must be priority in relation to the nature of the document filed. The document filed is a caveat, a warning, and, in terms, a prohibition to the registrar. All persons dealing with the land after that date are given notice of and must be held to have notice of the interest claimed. If A's caveat is filed on January 10th then $A$ gets priority by virtue of the act over dealings subsequent to that date. If $B$ files his caveat only on the 20th he gets priority by virtue of the act only over dealings subsequent to that date. In this way is not $A$ given some priority which $B$ may possibly not be given? If both A's and B's interest arose before the 10 th that might not be so, their priorities being determinable by the equitable rules, but if B's arose between the 10th and the 20th then A stands ahead of him while $B$ must compete under the equitable rules with all persons acquiring interests between the 10 th and 20 th or indeed, except $A$, before the 20 th at any time. Surely this is giving some effect to s. 97 without going any further.

Finally I think we ought not to disregard the judgment of Anglin, J. in Alexander v. McKillop which was the judgment of three out of five judges of the Supreme Court of Canada. It is true s. 97 of our act is not found in the Saskatchewan act, but the judgment there treats a caveat as coming within the meaning of an instrument' under the act and yet although this interpretation brings a caveat within the meaning of the general section of the Saskatchewan act as to priorities and thus practically makes the provisions of our 8.97 also a part of that act, the court did not attempt to decide the case in favour of Alexander on such an obviously simple ground and there are expressions in the judgment of Anglin, J. on P. 582 which point to his being of a contrary opinion.

My present view therefore is that s. 97 does not give anything more than protection against interests subsequently created and as I think it unnecessary for the purpose of the present appeal to decide the point, which is one of the very gravest importance, I should prefer to have the point argued more fully than it was in the present case before expressing a final opinion.

The next important Alberta decision, also in the Alberta Court of Appeal, was Re Royal Bank and Banque d'Hochelaga. ${ }^{110}$ The contest was between two equitable mortgagees, the Royal Bank by a deposit of duplicate certificate of title and the Banque d'Hochelaga by virtue of a subsequent mortgage in statutory form. The Banque d'Hochelaga filed a caveat and the Royal Bank did not. Stuart, J. took the same view as he did in the Stephens case and accordingly applied equitable rules and found for the Royal Bank as their interest was prior in time. The other three judges held that by Section 97 (now 152) the Banque d'Hochelaga obtained a new and absolute priority by filing its caveat. A passage from the decision of Simmons, J. is interesting: ${ }^{11}$

I feel bound to say that if to $\mathrm{s}$. 97 is ascribed the effect of absolute priority between two innocent equitable claimants that it is a somewhat startling innovation and one which to a large extent does away with the equitable jurisdiction of the court in regard to equitable claims, and I would be glad to be able to find in the reading of the section some qualification of this view. After careful consideration I cannot read into the section any qualification ...

In the Alberta case of Imperial Oil Ltd. v. Conroy and Berthiaume 112 the opinion was expressed that the words "filed," "registration" and "lodged" as they appear from time to time in ss. 131 to

"10 (1914) 7 W.W.R. 817.

11 Id., at 827.

112 (1954) 12 W.W.R. (NS) 569. 
148 (now Section 136 to 155) of The Land Titles Act are synonymous. McBride, J. amplified this statement: ${ }^{113}$

Sec. 145 [now Sec. 152] provides that registration by way of caveat shall have the same effect as to priority as the registration of any instrument under the Act. It would be a startling result to hold that because Imperial Oil has chosen to protect its leasehold estate from Conroy by registering a caveat-thereby giving notice to all the world of the interest claimed by it-rather than by registering the lease itself (when, it is conceded by Mrs. Berthiaume's counsel, the registrar would in due course have issued to Imperial Oil a certificate of title to the leasehold estate) that it had thereby deprived itself of the protection otherwise afforded by the Act to any one who, as I have held Imperial Oil did in this matter, deals and acts in good faith, for valuable consideration and in reliance on the title of his author as appearing in the register. This is the general and primary concept underlying our Land Titles Act as is pointed out by Rand, J. in the Turta case, and it is now so clearly established that it cannot in my view be restricted in the manner contended for by counsel for Mrs. Berthiaume. To hold otherwise, in my view, would be an artificial compartmenting of the provisions of The Land Titles Act and would largely destroy the usefulness of its provisions as to caveats above referred to. I cannot agree that the choice made by Imperial Oil to register and rely on a caveat and to leave its lease unregistered was in the language in the written argument of Mrs. Berthiaume's counsel, a lapse endowed with the seed of death.

Section 152 of the Alberta Act was taken from the Manitoba Act wherein substantially the same wording appears. Accordingly, the case Ukrainian Greek Orthodox Church of Canada v. Independent Bnay Abraham Sick Benefit, ${ }^{114}$ a decision of the Manitoba Court of Appeal, is applicable. The contest was between two purchasers of land from a cemetery company. The first purchaser tendered for filing a caveat but the registrar wrongly refused to file the same. The cemetery company in error then sold the land to the second purchaser who filed a caveat. The court held that the first purchaser had priority. His caveat was wrongfully rejected, and the fact that the registrar wrongfully refused to make the prescribed notation in the titles could not affect the priority which the filing confers. Adamson, C.J.M. observed:115

The Real Property Act, in giving priority to instruments on which caveats are based according to the time of filing, does do away with the maxim qui prior est tempore potior est jur: Alexander v. McKillop and Benjafield, supra. However, when specific performance is asked and the equities are so heavily against the plaintiff as they are in this case the maxim is a matter for consideration in deciding whether or not specific performance should be ordered.

With respect, I do not find that the case of Alexander v. McKillop supports this proposition, but support is found in another Manitoba Court of Appeal decision in Union Bank of Canada v. Turner.116 Cameron, J.A. said:117

In my modest opinion much is to be said for the view that, under the Land Titles Acts, certainty of title is conferred by the certificate of title; that the certificate as embodied with its endorsements is all that needs to be looked at to ascertain those who are interested in the property and what their interests may be and that, fraud apart, an unregistered instrument cannot affect a person dealing with a registered owner or with one whose interest duly appears on the register when that person protects himself by placing his own interest on the register as the Act provides. In other words the register is the essential element, the basis, the fons et origo, of title under the system. [Italics added].

113 Id., at 574.

114 (1959) 29 W.W.R. 97.

113 Id., at 119.

116 [1922] 3 W.W.R. 1138.

117 Id., at 1147 . 


\section{The Law in Saskatchewan}

At the outset it must be ovserved that in the Saskatchewan Act there is no comparable section to Section 152 of the Alberta Act. The question then arises whether in Saskatchewan the views of Stuart, J. as set out in the Banque d'Hochelaga ${ }^{118}$ case and in the Stephens ${ }^{119}$ case prevail to the effect that a caveat is just a warning and a prohibition that creates no new rights but prevents new ones arising in others thereafter and merely maintains the status quo, or whether, as suggested by Cameron, J.A. in Union Bank v. Turner ${ }^{120}$ the filing of a caveat puts the caveator in the same position as if his interest had been duly registered.

The leading Saskatchewan decision which supports the former view is Alexander v. McKillop and Benjafield,121 a decision of the Supreme Court of Canada. The facts are accurately set forth in Thom's Canadian Torrens System: ${ }^{122}$

The registered owner of lands, a company, agreed in writing to sell them to $P$., who assigned his interest in the contract to G., who then agreed to transfer the equitable interests thus acquired to A. Subsequently, without knowledge of A.'s interest, McK. \& B. acquired a like interest from G.; A. then lodged a caveat; following this McK. \& B., without inquiry or actual notice of the caveat, received an assignment of the original agreement of sale to $P$. and obtained the company's approval of it. In an action for specific performance it was held that as the purchasers were on equal terms as to equities except that $\mathbf{A}$. had priority in point of time at the date when his caveat was lodged, that such priority had been preserved by the lodging of the caveat and that the subsequent advantage which would otherwise have been secured by the company's approval of the assignment to Mck. \& B. was postponed to any equitable right which $\mathrm{A}$. might have to a transfer; the latter had the better equity and the caveat preserved it.

Thom then observes:

The Supreme Court of Canada, unlike the Manitoba Court of Appeal, in Ukrainian Greek Orthodox Church v. Independent Bnay Abraham Sick Benefit and Free Loan Assn. and Riverside Cemetery, supra, did not decide that the Torrens Act did away with the maxim qui prior est tempore potior est jure but rather confirmed that priority depended on recognized principles of equity; that a caveat if well founded prohibits any subsequent dealing under the Act and a fortiori outside the Act, in derogation of the claim. ${ }^{123}$

In Alexander v. McKillop and Benjafield, Anglin, J. stated:124

That the plaintiff's caveat, if it had been lodged only after the defendants had obtained the formal assignment of their vendor's contract and had procured the assent of the railway company thereto, would still have sufficed to entitle him to prevent the registration of the defendants as owners under a conveyance to them from the railway company seems to me improbable, inasmuch as, apart from the provisions of The Land Titles Act, the defendants would then have had a better right to call for the conveyance of the legal estate, and would in equity be entitled to the protection of it against the plaintiff's prior equitable title. But that question it is not now necessary to determine. [Italics added].

In Coast Lumber Co. v. McLeod, ${ }^{125}$ a transferee without notice of a prior equitable charge paid the purchase price and accepted delivery of a transfer but delayed registering the transfer for some months.

\footnotetext{
11. Supra, n. 52.

119 Supra, n. 48.

120 Supra, n. 58.

121 [1911] 1 W.W.R. 871.

122 Thom's Canadian Torrens System, supra, n. 102 at 660.

${ }^{123}$ See MacKay v. McDougall [1922] 2 W.W.R. 191, (1922) 64 S.C.R. 1, 68 D.L.R.245.

$124[1911]$ I W.W.R. 871 at 880.

123 (1914) 7 W.W.R. 113.
} 
Upon registration of the transfer he discovered that the chargee had filed a caveat subsequent to payment of the purchase price but prior to registration of the transfer. The Saskatchewan Court of Appeal (Newlands, J. dissenting), held that the unregistered transfer created only an equitable interest, that the chargee also had an equitable interest prior in time and the caveat protected it. The difficulty with the case is that in equity the holder of the unregistered transfer had the better equity. The maxim qui prior est tempore potior est jure does not apply in equity where a purchaser pays money without notice of a prior equitable interest and acquired at the same time the legal estate or the best right to call for it. In Dodds v. Hills ${ }^{126}$ Elwood, J. referred to Lilley, C.J. in In Re Scanlan as follows: ${ }^{127}$

Neither of them had title completed by actual entry on the register, that is a legal title as distinguished from an equitable one, but, either of them being a purchaser for value, could obtain priority of the other by getting in the legal title, or, in other words, securing priority of registration. [Italics added].

This suggests that the filing of the caveat by the chargee had the effect of getting in his legal estate and ousting the equity of the unregistered transferee, which was the better equity outside of statute.

The Supreme Court of Canada again had occasion to consider the effect of competing equities in McKay v. McDougall. ${ }^{128}$ McClellan, the registered owner of land sold the property to McDougall by agreement for sale. McDougall agreed orally to sell the same to McKay on June 21. The oral agreement was reduced to writing on June 22 and a caveat filed on June 30. About noon on June 22, McDougall agreed orally to sell to Rusconi. This oral agreement was reduced to writing on June 23. Rusconi's agent sent to McClellen a transfer in favour of Rusconi for execution and on June $26 \mathrm{McClellan}$ delivered the transfer to his bankers to be handled to Rusconi in receipt of the cash balance. On June 29 McClellen wrote McDougall that he had accepted Rusconi's offer and would not accept McKay on the contract. The Court found for McKay. Anglin J. said:129

I fully recognize that a Court of equity will not prefer one equity to another on the mere ground of priority of time until it has found by examination of their relative merits that there is no other sufficient ground of preference between them; that such examination must cover the conduct of the parties and all the circum. stances; and that the test of preference is the broad principle of right and justice which Courts of equity apply universally. ${ }^{130}$ Here after most careful consideration, I find nothing prior to the registration of McKay's caveat which disturbed the equality between the two equities in all respects other than priority of time, which is therefore effective and entitles McKay's equity to prevail.

Chief Justice Davies and Idington, J. found for McKay on the basis decided by Lamont, J. in the Saskatchewan Court of Appeal. Lamont, J. had decided the case on the basis that the equities were equal at the time McKay filed his caveat and as McKay's equity was prior in time his claim prevailed. It is to be noted that none of the Supreme Court Judges found for McKay on the basis that the filing of his caveat ousted prior equities.

In Bishop v. Western Trust Company ${ }^{131}$ in the Saskatchewan Trial

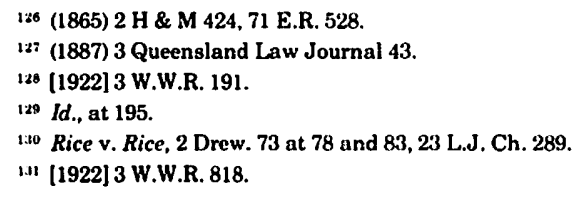


Division, five months after the decision in McKay v. McDougall, ${ }^{132}$ Bigelow, J. held that a caveat protecting an assignment by way of security from a registered owner filed after the execution of an agreement to give a mortgage, which agreement was dated prior to the caveat but registered after it, prevailed over the mortgagee's interest. The reasons of Bigelow, J. are unclear from the judgment but as he did not appear to expressly consider the comparative equities of the two claimants, it is a fair inference that his decision was based on the caveat ousting the prior equity.

In Friesen v. Elias, ${ }^{133}$ MacDonald, J. in a further Saskatchewan trial decision followed Bigelow, J. in the Bishop case and held that a caveat protecting a mortgage ousted a prior equitable mortgage based on a deposit of the duplicate certificate of title.

The Saskatchewan Court of Appeal again had occasion to consider the priority of unregistered instruments protected by caveat in Clark v. Barrick.134 In this case the registered owner in the mistaken belief that an offer to sell to Clark had lapsed agreed to sell to Hohmann. Hohmann accepted the offer prior to Clark, but Clark filed a caveat prior to Hohmann. The Court did not consider it necessary to examine the equities between Clark and Hohmann, but found for Clark on the basis that an unregistered instrument protected by a caveat must, when the claim is established, be given its full effect according to its tenor, regardless of any. other unregistered instrument whether prior or subsequent, not protected by a caveat, or protected by a caveat subsequent to the first caveat. Macdonald, J.A. giving the judgment of the Court proceeded on the basis that Wilkie v. Jellett ${ }^{135}$ (which established the existence of unregistered equitable interests outside of the Act) had been overruled. This is a matter of some doubt. In a Case Comment on Clark v. Barrick ${ }^{138}$ the authors' state that it is their view that Wilkie v. Jellett had not been overruled, that the Supreme Court of Canada decisions in the Benjafield ${ }^{138}$ case and the McKay v. McDougall ${ }^{139}$ case required the court to examine the equities, and that the same decision could have been reached on the basis that a caveat is a registered instrument and entitled to priority according to the date of registration.

Finally, in T. M. Ball Lumber Co. v. Zirtz and St. Mary's Parish Credit Union Ltd., ${ }^{140}$ the Supreme Court of Canada considered the effect of a caveat filed pursuant to an instrument which contained express acknowledgment of a prior equity. The Court held that the lodging of the caveat could not operate to defeat the prior equity. The Court confirmed the principle that a caveat was designed for the protection and not the creation of rights and rejected the view of the court of appeal that notwithstanding the reference to the prior equity in the instrument the statute "proprio vigore" ousts the prior equity. Martland, J. who delivered the judgment found it unnecessary to

\footnotetext{
1:2 [1922] 3 W.W.R. 191.

:is [1941]1 W.W.R. 127.

1.4 [1949] 2 W.W.R. 1009 .

1:3s (1895) 26 S.C.R. 282.

1:iti (1950) Can. Bar Rev. 456.

$1: 17$ (1895) 26 S.C.R. 282.

I.AN [1911]1 W.W.R. 871 .

1:99 [1922]3 W.W.R. 191.

101 (1961) 34 W.W.R. 625.
} 
decide whether the effect of filing a caveat is correctly stated in Clark v. Barrick. ${ }^{141}$

\section{E. SUMMARY OF AUTHORITIES}

1. Alberta

In Alberta it would seem from the Alberta Court of Appeal decisions in the Stephens ${ }^{142}$ case and the Banque $d^{\prime} H o c h e l a g a^{143}$ case that the Court will apply Section 152 of the Act in such a manner that of two innocent parties claiming under equitable titles, the first to lodge a caveat obtains priority, even though at that time the caveator had notice of the prior equity.

It is to be observed, however, that there are arguments to a contrary effect, and it is also to be noticed that the Supreme Court of Canada has never dealt with the effect of Section 152 of the Alberta Act. In all of the four Supreme Court of Canada decisions, Wilkie v. Jellett, ${ }^{144}$ Alexander v. McKillop \& Benjafield, ${ }^{145}$ McKay v. McDougall ${ }^{146}$ and T. M. Ball Lumber Co. v. Zirtz, ${ }^{147}$ dealing with Land Titles Acts in which Section 152 is not found, the Court deemed it necessary to enquire into the equities affecting the competing claimants, and in no case was it held that a caveat had the effect of ousting prior equities. There is, in fact, obiter dictum in the Supreme Court decisions to the contrary. It is to be observed that the Supreme Court of Canada has in its decisions consistently resisted any tendency, in the Land Titles Acts which it has considered, to oust the equitable jurisdiction of the Court in regard to equitable claims.

It is suggested that if the question of priority between equitable claimants arose under the Alberta Act, particularly with respect to dealings other than with the registered owner, then, although the stronger argument is undoubtedly that of Beck and Simmons, J.J. (see above), the Supreme Court of Canada might, if it wished, find its way clear to form an opinion contrary to the presently prevailing Alberta decisions. Provincial legislation such as Section 152 ousting the equitable jurisdiction of the Court is hardly a provision which one can expect the Supreme Court of Canada to embrace with enthusiasm. The writer can imagine a number of arguments which the Supreme Court of Canada might use to justify a contrary decision:

(1) It might follow the reasoning of Stuart, J. in the Stephens ${ }^{148}$ and Banque d'Hochelaga ${ }^{149}$ decisions which argues for a more restricted effect for Section 152.

(2) Section 152 speaks only of the effect of a caveat "as to priority". This is a clear reference to Section 58 of the Act which deals with priority of registration and reads as follows:

58. Instruments registered in respect of or affecting the same land have priority the one over the other according to the time of registration and not accord. ing to the date of execution.

\footnotetext{
14 [1949] 2 W.W.R. 1009.

162 (1913) 5 W.W.R. 201.

10:1 (1914) 7 W.W.R. 817.

114 (1895) 26 S.C.R. 282.

145 [1911]1 W.W.R. 871 .

140 [1922] 3 W.W.R. 191

14: (1961) 34 W.W.R. 625.

14n (1913) 5 W.W.R. 201.

149 (1914) 7 W.W.R. 817.
} 
Section 152 does not say that filing of a caveat shall have "the same effect" as the registration of any instrument, which would have been a clear reference to Section 57 of the Act:

57. So soon as registered every instrument becomes operative according to the tenor and intent thereof, and thereupon creates, transfers, surrenders, charges or discharges, as the case may be, the land or the estate or interest therein mentioned in the instrument.

It can be argued that Section 58 of the Act merely provides that when you have two registered instruments, the important date to establish priorities is the date of registration and not the date of the instrument itself. If Section 152 had been intended to be interpreted as if it also referred to Section 57 , it would have been a simple thing to say. ${ }^{150}$

(3) Considering the matter for the moment in an oil and gas context, Section 176(4) of the Alberta Act provides in essence that no claim against the assurance fund arising out of a disposition of an interest in mines and minerals shall be made in respect of any acquisition of minerals from a registered owner unless the Registrar has issued in respect of that disposition a mineral certificate. Section 176(2) provides as follows:

176. (2) In the case of a disposition by sale, lease, assignment, agreement or other instrument executed on or after the twenty-ninth day of March, 1949, by which the person who purports to be the registered owner of an interest in mines and minerals disposes of all or any part of such interest, any party to the disposition and his successors and assigns may apply to the Registrar for a mineral certificate. [Italics added].

It is to be noted that Section 176(2) limits the parties who are entitled to apply for a mineral certificate to those acquiring under a disposition from the registered owner. It follows that parties acquiring equitable interests other than from the registered owner cannot apply for a mineral certificate and cannot, therefore, claim against the assurance fund. It can be argued that this is an indication that such parties are not intended by the Act to be entitled to rely on the register (Section 203).

(4) The equitable principles described in Part II of this paper were accepted as basic to English law for centuries. These principles should be applied unless a statute provides either expressly or by necessary intendment that they shall cease to apply. The Alberta Land Titles Act has by various sections expressly dealt with these important principles and states that to the extent provided in the Act they shall not apply. Section 203 clearly abrogates the doctrine of constructive notice by express reference, but only to the extent that it applies to persons "contracting or dealing with or taking or proposing to take a transfer, mortgage, encumbrance or lease from the owner of land in whose name a certificate of title has been granted." Accordingly, except to this extent, the doctrine of constructive notice continues to apply unless it is inconsistent with other provisions of the Act. There are no other provisions of the Act with which the continued application of the doctrine of constructive notice to persons contracting otherwise than with the owner of land is necessarily inconsistent, and such an important and fundamental 
doctrine should not be abrogated by vague implication. Was it this that made Beck, J. say in the Stephens case: ${ }^{151}$

The claim of each caveator must of course be grounded immediately or mediately upon a dealing eith the registered owner.

\section{Saskatchewan}

The cases from Saskatchewan courts indicate a state of the law not unlike that in Alberta but with significant differences. In the absence of Alberta Section 152, the Saskatchewan Court of Appeal has reached much the same result by holding that the effect of the filing of a caveat is to get in the legal estate, thus ousting the prior equity. ${ }^{152}$ Clark v. Barrick $k^{153}$ held that an unregistered instrument protected by caveat must when the claim is established be given effect according to its tenor regardless of any other unregistered instrument whether prior or subsequent, not protected by a caveat, or protected by a caveat subsequent thereto. Thom's Canadian Torrens Systems, Second Edition, has summarized the position under the Saskatchewan cases as follows: 154

...the caveat in the absence of any acknowledgment of the prior equity in the instrument founding the caveat, may well elevate the unregistered equitable right of the caveator to the status of a hybrid inchoate legal right.

By this reference to an "inchoate" right is meant that the interest referred to in the caveat must, if required, be confirmed by a court.

It is submitted that the law as indicated by Coast Lumber Co. v. $M_{\text {cLeod }}{ }^{155}$ and by Clark v. Barrick ${ }^{156}$ may not be entirely consistent with the various decisions of the Supreme Court of Canada referred to above, which, as previously suggested, show a marked tendency in every case to examine the respective equities of the parties, notwithstanding the existence of a caveat. Martland, J. in T. M. Ball Lumber Co. v. Zirtz ${ }^{157}$ declined to decide whether Clarke v. Barrick ${ }^{158}$ correctly described the effect of filing a caveat in Saskatchewan, as he was able to decide the case on the basis that the instrument upon which the caveat was based contained an express reference to the prior equity. For the same reasons as indicated above with reference to Alberta law, it is suggested that the Supreme Court of Canada in a proper case from Saskatchewan might yet strike a blow in defence of its equitable jurisdiction.

\section{F. DISCUSSION}

It is clear that under the Alberta Land Titles Act, the bona fide purchaser for value from the registered owner, which would include a lessee under a petroleum and natural gas lease (Section 203), who enters his transfer (or lease as the case may be) on the register, acquires an indefeasible right unaffected by prior equitable interests, whether or not such purchaser had notice of such interest. Nor would it appear to matter whether the lessee under a petroleum and natural

\footnotetext{
1si (1913) 5 W.W.R. 201 at 210.

ita Coast Lumber Co. v. McLeod (1914) 7 W.W.R. 113.

1sa [1949] 2 W.W.R. 1009.

1s4 Thom, supra, n. 102 at 665.

$15 s$ (1914) 7 W.W.R. 113.

1:* [1949] 2 W.W.R. 1009.

is7 (1961) 34 W.W.R. 625

isN [1949] 2 W.W.R. 1009.
} 
gas lease registers the lease itself or files a caveat pursuant to such lease. ${ }^{159}$

However, with respect to parties acquiring interests from or under the lessee, and not from the registered owner, the instruments creating those interests are not themselves registrable. Under the Torrens system in its usual application the legal estate is acquired by registration of the instrument itself. Accordingly, it is of the utmost significance what effect is attributed to the filing of a caveat. It is apparent both from the cases from Alberta and those from Saskatchewan that there are conflicting interpretations:

Interpretation 1:

Alberta and Saskatchewan-The caveat does not increase the rights of the caveator and he must compete with other unregistered equitable claimants to establish his priority. The caveat merely maintains the status quo and prevents subsequent interests arising in priority to it. Section 152 of the Alberta Act does not have a contrary effect.

Interpretation 2:

Alberta-If the validity of the caveat is established, then by virtue of Section 152 of the Alberta Act, the caveat has the same effect as registration of an instrument and accordingly, the caveator is by virtue of Section 203 placed in an even stronger position than the equitable purchaser for value without notice; that is to say, in the absence of fraud, he is prior in right even to those prior equities of which he had notice.

Interpretation 3:

Saskatchewan-If the validity of the caveat is established, then in the absence of fraud or acknowledgment of the prior equity in the instrument concerned, the filing of a caveat gets in the legal estate and places the caveator in the same position as a purchaser for value without notice under the equitable rules discussed in Part $B$ above.

It may now be instructive to consider the possible effect of the foregoing on the fact situation posed for consideration in the Introduction to this paper.

Applying Interpretation 1 to the facts, it is clear that B and C by filing caveats do not get in the legal estate. The caveats do not increase their interest. Their position is one of competing equitable claimants only, and it becomes necessary to establish who has the better equity; $B$ under the declaration of trust or $C$ under the farmout agreement. $B$ was first in time. Both parties have the right to call for a conveyance of their interests, but C's right is conditional upon the fulfillment of his obligations under the farmout agreement. B neglected to file a caveat at once. Does this raise an estoppel against $B$ ? If so, $\mathrm{C}$ would have the better equity. But was $\mathrm{C}$ or his solicitor negligent in their title investigation such that $B$ could argue that a proper investigation would have disclosed his interest? It is clear that the question who has the better equity is one which can only be answered after a careful look at and balancing of all the surrounding facts. It is suggested that the court would probably hold on these facts that the

1.:9 Imperial Oil v. Conroy (1954) 12 W.W.R. (NS) 569. 
neglect by $B$ to file a caveat such as to give notice of his claim, when it would have been a simple thing to do, gives to $C$ the better equity such that he takes clear of B's interest. B's only remedy would be against $A$ for breach of trust. He is presumably entitled to $50 \%$ of A's reserved royalty. On the other hand, if the court held on the facts that $B$ had the better equity, then $C$ would only get a $50 \%$ working interest in the lands, because that was all $A$ had to give him. In that event the following interesting questions arise:

(1) What is C's remedy, if any, against A?

(2) What is C's remedy, if any, against his solicitors who gave a title opinion to $\mathrm{C}$ as to A's interest?

It is to be remembered that the farmout agreement contained a clause stating that $A$ did not warrant his title to the lands. The effect of this clause may in certain circumstances be doubtful. Suppose that A held the entire $100 \%$ working interest in trust for B. C would then have received nothing. Surely $C$ could claim a total failure of consideration and recover against $A$. But what would $C$ be entitled to recover; only his costs of the earning well, or his damages for loss of a valuable property? It is suspected the former would be the case, but it is beyond the ambit of this paper to consider that problem and it is merely raised for consideration. In any event, there is no total failure of consideration under our facts as $A$ would have received a $50 \%$ interest. It is suggested that $C$ would have no action against $A$ unless he could establish fraud on the part of $A$.

What then of a claim by $\mathrm{C}$ against his solicitors? $\mathrm{C}$ relied upon his solicitors' title opinion as to the interest of A before drilling the well. The opinion was incorrect. The question is whether the solicitors did all that a prudent solicitor should do, or whether they were remiss in their duties. It is to be noted that they did not ask for or review A's correspondence file, and they did not obtain a certificate or declaration from $A$ to the effect that all relevant documentation had been disclosed to them. On the other hand, the document file did disclose a complete chain of title. Much might also depend upon how the opinion was worded, but it is suggested that the solicitors of $C$ should notify their insurers at once.

Let us apply to the facts Interpretation 2 as set forth by the Alberta cases, assuming the lands are situated in the Province of Alberta. It is unnecessary to consider the priority of the equitable interests of $B$ and C. Section 152 establishes this based on the order of registration of the caveats. What is the effect of the filing of the caveat by $\mathrm{C}$ based on the farmout agreement? The caveat has the same effect as to priority as the registration of an instrument under the Act. $C$ would therefore take clear of B's interest whether C was aware of B's interest or not. C's caveat based on the assignment of the lease would gain the same priority on the register as the caveat protecting the farmout.

The position may change somewhat under Interpretation 3 . What is the effect in Saskatchewan (in the absence of a section comparable to Section 152 of the Alberta Act) of the filing of the caveat by $\mathrm{C}$ based on the farmout agreement? The farmout agreement is an executory agreement only, and it is difficult to imagine how the filing of a caveat based on that document gets in any legal estate. However, 
the drilling of the earning well without notice of B's equitable interest makes $\mathrm{C}$ a purchaser for value without notice. When $\mathrm{C}$ files his caveat based on the assignment of the lease, this has been held to be equivalent to getting in the legal estate which, under the old equitable rules, ousts any prior equities. But B filed his caveat protecting his beneficial interest prior to $\mathrm{C}$ filing his caveat based on the lease assignment. Under the equitable rules when $C$ does not get in the legal estate at the time of his purchase, he may get in the legal estate subsequently and gain priority over earlier equitable interests even though he has received notice of such earlier equitable interest prior to getting in the legal estate, but this latter right is subject to the qualification that when B's equitable interest is a trust of the legal estate, $C$ cannot avail himself of the legal estate as against B's prior equitable interest. In the facts of our case, B's interest is a trust of A's legal estate. Consequently, C would hold B's interest in trust for B. Presumably in these circumstances it would then be necessary to examine the equities between $B$ and $C$ to establish whether in fact $B$ had the better equity, and the same considerations entered into under Interpretation 1 would apply.

\section{G. CONCLUSIONS AND RECOMMENDATIONS}

There is evident in the cases a variance of opinion between the Supreme Court of Canada and the Courts of Appeal of Alberta and Saskatchewan. The Supreme Court of Canada has in its decisions exhibited a reluctance to relinquish its equitable jurisdiction. It remains to be seen the extent to which this will manifest itself to alter the existing provincial decisions relating to caveats protecting unregistered and unregistrable interests, particularly with respect to interests obtained in dealings other than with the registered owner.

There is much to be said for an interpretation of the Torrens system which makes unnecessary further application of the archaic, confusing and uncertain principles of equity. However, such principles should only be replaced by provisions which adequately protect parties formerly protected by equity. The interpretations of the Alberta and Saskatchewan Courts of Appeal go far to incorporate a deeds system into the Torrens system, but without all the advantages of the deeds system. Under a deeds system the deed itself must be registered, whereas caveats frequently do not have the document attached and merely refer to documents in the vaguest of terms. Questions may arise as to the extent to which a caveat is effective because it does not accurately reflect the interest being claimed in the document upon which it is based. ${ }^{160}$ The writer suggests that if the interpretations of the Alberta and Saskatchewan Courts of Appeal are correct such as to establish a form of deeds system, then there should be a corresponding obligation on the caveator to attach to his caveat the instrument upon which it is based.

In view of the extremely high values normally attributed to oil and gas properties, it is most likely that if the question arises in an oil and gas context, it will be ultimately brought before the Supreme Court of Canada for a decision. In view of the possible attitude which this Court might adopt, a party should take great care to place him-

iwo Ruptash and Lumsden v. Zawick [1956] S.C.R. 347. 
self (or his client) in the best possible position and in this regard the writer has the following comments:

(1) Caveats should always be filed as soon as possible and a general registry search made for executions to give the caveator the best available protection under the Land Titles Acts. Where possible the document upon which the caveat is based should be attached and incorporated into the caveat by reference.

(2) Before concluding a disposition of oil and gas interests, a complete title investigation should be conducted of the oil and gas interests concerned, which title investigation should include:

(i) a complete search of the agreement files and correspondence files of the grantor,

(ii) a follow-up investigation of all matters appearing therein which could give rise to an adverse interest in a third party,

(iii) obtaining a statutory declaration or certificate from the grantor or a responsible officer or officers of the grantor of the interest concerned that all documents or instruments affecting the interest concerned have been disclosed to the grantee or his solicitors, and if possible attaching thereto a schedule of such documents (this for the protection of the solicitor conducting the investigation),

(iv) a title search at the land titles office of the land concerned, and

(v) a mineral certificate should be obtained when possible.

(3) Care should be taken with respect to clauses negating title warranty. It is customary to find the following type of clause in farmout and sale agreements:

The farmor (vendor) does not make any warranty as to title, and does not promise or agree to convey to the farmee (purchaser) any better or greater right, title or interest in and to the lands than that which it now owns by virtue of the lease.

A farmee or grantee of an interest is well advised to insist that a proviso be added to this clause to the effect that "the farmor has not assigned, transferred, conveyed or in any way encumbered its interest in the lease to the extent that it relates to the lands concerned." 